\title{
Modelling of Sorghum (Sorghum bicolor) Growing Areas under Current and Future Climate in the Sudanian and Sahelian Zones of Mali
}

\author{
L. Traoré1,2, O. D. Bello ${ }^{1 *}$, F. Chabi', I. Balogoun ${ }^{1,3}$, I. Yabi', M. Y. Issifou ${ }^{5}$, E. L. Ahoton1, A. Togola², \\ A. Saïdou ${ }^{1}$
}

${ }^{1}$ Integrated Soil and Crop Management (ISCM) Unit, Soil Sciences Laboratory, School of Plant Production Sciences and Techniques, Faculty of Agronomic Sciences, University of Abomey-Calavi, Cotonou, Benin

${ }^{2}$ Laboratoire d'Agro-Physio-Génétique et de Biotechnologie végétale, Institut Polytechnique Rural de Formation et de Recherche Appliquée (IPR/IFRA) de Katibougou, Katibougou, Mali

${ }^{3}$ Ecole de Gestion et de Production Végétale et Semencière (EGPVS), Université Nationale d'Agriculture (UNA),

Kétou, Bénin

${ }^{4}$ Pierre PAGNEY Laboratory “Climate, Water, Ecosystem and Development”, University of Abomey-Calavi, Faculty of Letters, Arts and Human Sciences, Department of Geography and Spatial Planning, Cotonou, Benin

${ }^{5}$ Cartography Laboratory (LaCarto), Institute of Geography, Land Management and Environment (IGATE), University of Abomey-Calavi (UAC), Abomey-Calavi, Benin

Email: ^bellooroudaouda@gmail.com

How to cite this paper: Traoré, L., Bello, O. D., Chabi, F., Balogoun, I., Yabi, I., Issifou, M. Y., Ahoton, E. L., Togola, A., \& Saïdou, A. (2021). Modelling of Sorghum (Sorghum bicolor) Growing Areas under Current and Future Climate in the Sudanian and Sahelian Zones of Mali. American Journal of Climate Change, 10, 185-203. https://doi.org/10.4236/ajcc.2021.102009

Received: February 23, 2021

Accepted: June 27, 2021

Published: June 30, 2021

Copyright (c) 2021 by author(s) and Scientific Research Publishing Inc. This work is licensed under the Creative Commons Attribution International License (CC BY 4.0).

http://creativecommons.org/licenses/by/4.0/ (c) Open Access

\begin{abstract}
Climatic variability is one of the main constraints of agriculture in Mali, which will certainly affect long-term sorghum yields. The objective of the present study was to assess the effect of climate variability on sorghum production areas by 2050 in the Sudanian and Sahelian zones of Mali considering three climate scenarios: current scenarios (RCP 2.5), optimistic scenarios (RCP 4.5) and pessimistic scenarios (RCP 8.5). Therefore, 11,010 occurrence points of sorghum (Sorghum bicolor) were collected and associated with the environmental variables of the three climatic scenarios according to the maximum entropy approach (Maxent). Sorghum environmental data and points of occurrence were obtained from AfriClim and GBIF databases, respectively. The correlations carried out and the Jackknife test allowed us to identify variables that contributed more to the performance of the model. Overall, in the Sudanian zone, the suitable area for sorghum production which currently represents $37 \%$ of the area of the district of Koulikoro will increase up to $51 \%$ by 2050 considering the optimistic scenario (RCP 4.5). Furthermore, considering the
\end{abstract}


pessimistic scenario (RCP 8.5), the suitable zones for sorghum production will experience a decrease of $10 \%$. In the Sahelian zone, the suitable zones for sorghum production that represent $55 \%$ of San district area considering the RCP 2.5 scenario will experience a decline of $24 \%$ by 2050 considering both the optimistic (RCP 4.5) and pessimistic (RCP 8.5) scenarios. It is suggested to carry out investigations on potential sorghum yield prediction in both study areas in order to identify suitable production areas of the crop in the near future (2050) and long term (2100) as adaptation strategies and resilience of farmers to climate change.

\section{Keywords}

Modeling, Maxent Model, Sorghum, Climatic Scenarios, Sudan-Sahel Region, Mali

\section{Introduction}

Climate change is likely to affect the profitability of cropping systems in the future in most of the developing countries in general and Mali in particular (Talacuece et al., 2016). In these areas, crop yields are highly dependent on the weather parameters especially temperature and rainfall (Talacuece et al., 2016). Indeed, one of the consequences of the effects of climate change would be lower crops' yields therefore increase risks of food insecurity (Newman, 2016). Climate change could affect the distribution and the extinction in the next century of many plant species (Giam et al., 2010). Nowadays, it is one of the main threats to plant biodiversity and to a lesser extent animal biodiversity (IPCC, 2013). Sorghum is hardly exempt from this situation; indeed, it is one of the most cultivated cereals in the world due to its strong involvement in human and animal nutrition.

In Mali, sorghum is cultivated from the south to the north (Soumaré, 2004) of the country with more than 1700 ecotypes identified during surveys (Touré \& Diallo, 2004) and 70\% of these ecotypes identified belong to the Guinean race (Touré, 2016). The area allocated to sorghum cultivation is about $3.34 \%$ and it is an important product for the basic food of the population. However, this production is threatened by the significant loss of varietal diversity in recent years due to climate change and its effects such as recurrent and irregular droughts, rainfall deficits, heavy rainfall events, devastating floods, etc. (Traoré et al., 2013; Ouattara et al., 2019).

Simulation models were widely used to predict the behaviour or performance of crops under different environmental conditions (increasing temperatures, decreasing rainfall, etc.) (Soufiyanou et al., 2019). Modelling allows species distribution study and is an important predictive tool in conservation ecology (Guisan \& Zimmermann, 2000; Elith et al., 2006; Phillips et al., 2006; Franklin, 2009; Padalia et al., 2014; Soufiyanou et al., 2019). Thus, it allows responding to the major issues of understanding, describing and predicting the potential range of spe- 
cies and identifying the factors that determine its distribution and production potential (Guisan \& Zimmermann, 2000; Soufiyanou et al., 2019). Similarly, the adjustment of agricultural practices as adaptation strategies to the effects of climate change can be carried out using modelling (Lobell \& Field, 2007; Sinclair et al., 2014). Despite the progress of African agriculture nowadays, the use of climate models for planning agricultural activities is still in development in Mali. The results of modeling studies in the climate field, even if they sometimes reveal controversies (Sultan \& Gaetani, 2016), are of great importance in view of the significant impact that climate change will have on food security in the future (Wheeler \& von Braun, 2013). The objective of the present study was therefore to assess the impact of climate variability under different climatic scenarios on the suitable zones for sorghum production in the Sudanian and Sahelian environments of Mali. We started from the hypothesis that a variation in the environmental and climatic conditions would lead to a significant decrease of the suitable area for sorghum cultivation in the short and long terms.

\section{Study Area}

The work was carried out in the districts of Koulikoro and San in Mali (Figure 1). The district of Koulikoro is located in the Sudanian zone $60 \mathrm{~km}$ from Bamako (political capital of Mali). It is located between longitude $-8.9^{\circ} 32^{\prime}$ West and $12^{\circ} 56^{\prime}$ North latitude at an altitude of $332 \mathrm{~m}$ above sea level on the $900 \mathrm{~mm}$ isohyet (Bakary, 2010). The area is characterized by a Sudano-Sahelian climate with an average annual rainfall varying between 700 and $900 \mathrm{~mm}$ (Bakary, 2010). The growing season generally starts in early June lasting in October. The district is an agropastoral zone, millet, sorghum, maize, rice, fonio and cowpea are the main food crops. Market gardening is also practiced. Cotton is the main cash crop. The vegetation of the zone is characterized by a savannah with trees and shrubs. The herbaceous carpet is dominated by annual grasses with Combretum lecardii, Combretum glutinosum, Guiera senegalensis, Prosopis africana, Sclerocarya birrea, Spondias monbin, as dominant trees (Bakary, 2010). The main soil types encountered in the area are tropical ruby ferruginous soils. The district of San, however, is located in the Ségou region in the Sahelian zone of Mali at West longitude $-4^{\circ} 9^{\prime}$ and $13^{\circ} 3^{\prime}$ North latitude, altitude of $287 \mathrm{~m}$ above sea level. The average annual rainfall varies between $500 \mathrm{~mm}$ and $800 \mathrm{~mm}$. The rainy season also start in mid-June and last in October. There is also a delay in the rainy season with an average of three months of rainfall (Coumbiti, 2019). Millet and sorghum are the main food crops. The vegetation is dominated by Faidherbia albida, Adansonia digitata, Vitelaria Paradoxa, Balanites aegyptiaca, Ceiba pentandra, Khaya senegalensis, Parkia biglobosa etc. The soils are clayey, sandy, lateritic and gravelly.

The geographical coordinates (longitude and latitude) in decimal degrees of Sorghum bicolor were collected in the phytogeographical regions (Sudanian and Sahelian) of Mali in 2019 and in West Africa (available on the GBIF website) 


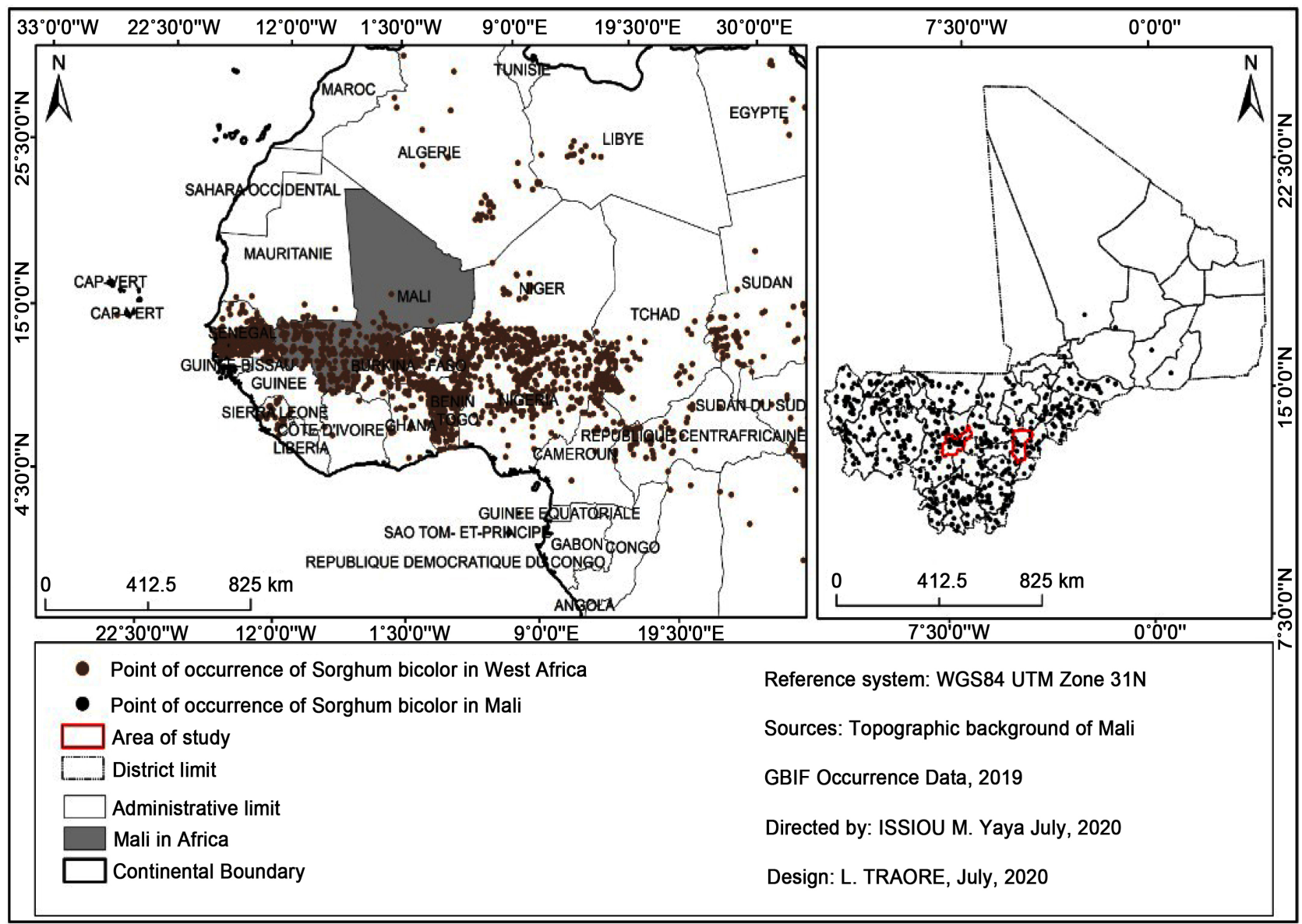

Figure 1. Location of occurrence data used.

(Figure 1). A total of 11,010 Sorghum bicolor occurrence data were collected.

\section{Material and Methods}

\subsection{Environmental Variables Used and Simulation Models}

The current climate data are derived from climate data (1950-2000) collected from the database of Worldclim version 1.4. For the future climate projections, the regional circulation ensemble model "AFRICLIM 3.0: high resolution ensemble climate projections for Africa" (available at

https://webfiles.york.ac.uk/KITE/AfriClim/) was used. This model is more suitable compared to the global circulation models (Platts et al., 2015). Concerning this model, projections to 2050 were retained considering three scenarios. The climate layers used are those of 30 -second arc resolution (i.e. a resolution grid of approximately $1 \mathrm{~km} \times 1 \mathrm{~km}$ ). The bioclimatic data, were collected from database of Shuttle Radar Topography Mission (SRTM) images (available at

https://earthexplorer.usgs.gov). The resulting dataset was subjected to correlation analysis in order to eliminate weakly correlated variables (Elith et al., 2010). This analysis was performed with ENMTools 1.3. Table 1 presents the environmental variables used to generate the potential distribution maps of Sorghum 
Table 1. Environmental variables used to generate the potential distribution maps of Sorghum bicolor species in West Africa and in Mali.

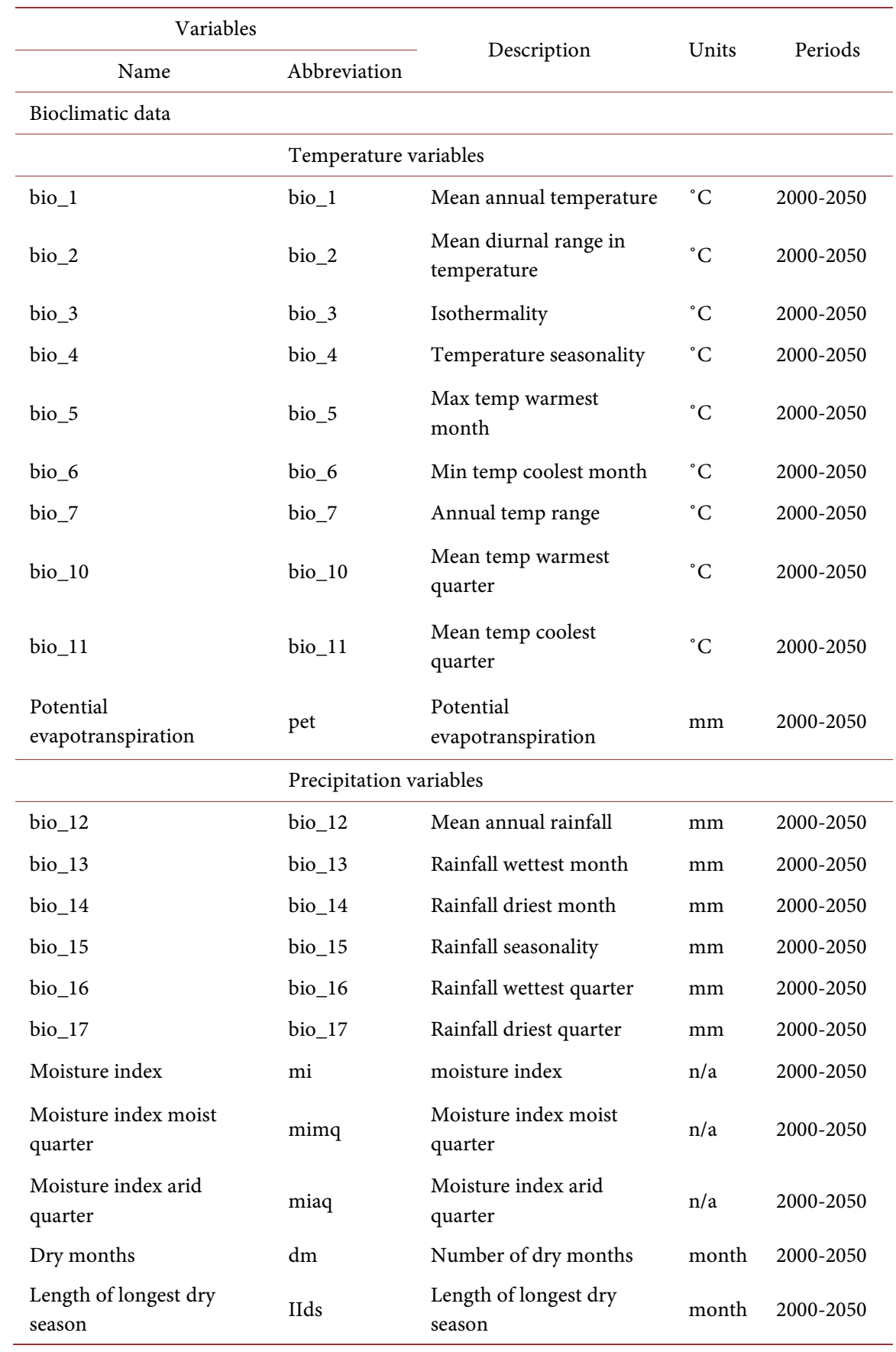

\section{bicolor species.}

\subsection{Data Processing and Analysis}

\subsubsection{Modeling and Model Evaluation}

The first category consisted of $25 \%$ of the occurrence data was used to test the prediction model. The second category, which included $75 \%$ of the occurrence data, was used to calibrate the model in five replicates by cross-validation. The 
Jackknife test was performed to determine the importance of the individual environmental variables used. The Area Under the Curve (AUC) statistic (Phillips et al., 2006; Soufiyanou et al., 2019) was used to assess the performance of the model as well as the True Skill Statistics (TSS) (Allouche et al., 2006, Soufiyanou et al., 2019). The model perform well if the AUC value is greater than 0.90 , fair when the value is $0.75 \leq \mathrm{AUC} \leq 0.90$, bad if the AUC value $<0.75$. The TSS is the model's ability to accurately detect true presences (sensitivity) and true absences (specificity). A model with a TSS $\leq 0$ indicates a random prediction; whereas a model with a TSS closes to 1 (TSS $>0.5$ ) has good predictive power (Allouche et al., 2006; Soufiyanou et al., 2019).

\subsubsection{Mapping of Modeling Results}

The modeling results were integrated into ArcGIS 10.5 software for mapping the extent of sorghum agro-ecological zones under current and future climatic conditions. The gross probability distribution obtained by the model was estimated as a measure of the probability of sorghum occurrence. A four-level categorization of this probability was made for the discrimination of sorghum agro-ecological zones through the "raster calculator" tool of the same software. In addition, in the present study, a sorghum agroecological zone is considered completely non suitable when the probability of occurrence of the species is less than 0.5 . If this probability is between 0.5 and 0.53 the zone is not suitable, when the probability values vary between 0.53 and 0.55 it indicates a suitable zone, while those above 0.55 are considered very suitable zones for sorghum production in the district concerned by the study.

\section{Results}

\subsection{Contribution of Variables to the Prediction of the Sorghum Agro-Ecological Zone}

The contribution of the preselected variables to the prediction of sorghum growing area in the two climate zones differed between the two climate scenarios. Tables 2-4 show the contribution of the variables of the prediction of sorghum growing areas for the scenarios RCP 2.5, RCP 4.5 and RCP 8.5, respectively. The proportions observed in the last column of Table 2 relate to the reduction in the model predictive power when the values of a given variable are randomly swapped between background and presence points. A high value indicates a high importance of the variable concerned. Under current climate conditions (Table 2 ), a proportional variation (\%) in the contribution of variables to model prediction is observed. Variables such as: seasonality of rainfall (bio15), annual rainfall (bio12), number of dry months ( $\mathrm{dm}$ ), humidity index wet quarter (mimq), rainfall of the wettest month (bio13) cumulate a contribution of $76.8 \%$ and are therefore the variables that have contributed the most to the prediction of the sorghum agroecological zones (considering the RCP 2.5 scenario) from the point of view of their order of integration in the prediction model. 
Table 2. Contribution of variables to the prediction of the sorghum production area considering the current scenario RCP 2.5 .

\begin{tabular}{ccc}
\hline & Scenario RCP 2.5 & \\
\hline Variable & Percent contribution & Permutation importance \\
\hline bio15 & 21.3 & 2 \\
bio12 & 19.5 & 13.3 \\
dm & 15 & 7.4 \\
mimq & 10.5 & 2.9 \\
Bio13 & 10.5 & 6.3 \\
bio7 & 4.8 & 10.8 \\
Bio2 & 3.9 & 7.1 \\
IIds & 2.5 & 1.6 \\
bio3 & 2.5 & 12.2 \\
bio14 & 2 & 1.2 \\
\hline
\end{tabular}

Table 3. Contribution of variables to the prediction of the sorghum production area considering the RCP 4.5 scenario.

\begin{tabular}{ccc}
\hline \multicolumn{3}{c}{ Scenario RCP 4.5 } \\
\hline Variable & Percent contribution & Permutation importance \\
\hline bio13 & 30 & 14.4 \\
bio16 & 21.7 & 6.8 \\
bio12 & 20.1 & 12.9 \\
mimq & 4.8 & 8.8 \\
bio7 & 4.7 & 9 \\
bio17 & 4.4 & 3.9 \\
dm & 2.7 & 1.5 \\
bio2 & 2.6 & 5.3 \\
\hline
\end{tabular}

Table 4. Contribution of variables to the prediction of the sorghum production area considering the RCP 8.5 scenario.

\begin{tabular}{ccc}
\hline & Scenario RCP 8.5 \\
\hline Variable & Percent contribution & Permutation importance \\
\hline bio13 & 30.1 & 13.1 \\
bio16 & 21.6 & 6.4 \\
bio12 & 20.2 & 10.3 \\
bio17 & 4.9 & 3.8 \\
mimq & 4.6 & 12.3 \\
pet & 3.9 & 5.7 \\
dm & 2.6 & 0.8 \\
bio2 & 2.4 & 4.7 \\
bio7 & 2.1 & 7.4 \\
bio3 & 2.0 & 6.7 \\
\hline
\end{tabular}


Considering the results of Table 3, in terms of the importance of permutation, the annual precipitation variable, the ratio of the daily thermal amplitude to the annual thermal amplitude (bio3), the annual temperature variation (bio7), the number of dry months $(\mathrm{dm})$, the mean of daily temperature variation (bio2) and the rainfall of the wettest month (bio13) reduce the model's prediction to nearly $57.1 \%$. These variables were the most determinant in the prediction of the spatio-temporal dynamics of sorghum agroecological zones when considering the RCP 4.5 scenario. However, variables such as the seasonality of rainfall, the wet quarter humidity index (mimq), the duration of the longest dry season (IIds), the rainfall of the wettest month (bio13), the annual rainfall (bio12), the rainfall of the wettest quarter (bio16) cumulated a contribution of $71.8 \%$ and are therefore the variables that have contributed most to the prediction of sorghum agroecological zones (Table 3 ). Regarding the importance of permutation, the annual rainfall variable (bio13), the annual rainfall (bio12), the annual temperature variation (bio), the wet quarter humidity index (mimq), the rainfall of the wettest quarter (bio16), the mean daily temperature variation (bio2) cause the reduction of the predictive power of the model when permuted between 5.3 and $14.4 \%$. It can only be deduced that the permutation of these variables reduces the predictive power of the model to nearly $57.2 \%$. Consequently, these variables were the most decisive in the prediction of the spatio-temporal dynamics of the agroecological zones of Sorghum bicolor distribution. However, rainfall of the driest quarter (bio17) and the number of dry months $(\mathrm{dm})$ had little influence on the discrimination of these zones.

According to the pessimistic scenario (Table 4), we note that rainfall of the wettest month (bio13), rainfall of the wettest quarter (bio16), annual rainfall (bio12), cumulate a contribution of $71.9 \%$ and are therefore variables contributing the most to prediction of sorghum agroecological zones considering the pessimistic scenario. Regarding the importance of permutation, annual rainfall (bio13), humidity index wet quarter (mimq), annual rainfall (bio12), annual temperature variation (bio7), ratio of the daily thermal amplitude to the annual thermal amplitude (bio3), rainfall in the wettest quarter (bio16), potential evapotranspiration (pet), mean daily temperature variation (bio2) cause the model's predictive power to be reduced by nearly $4.7 \%$ to $13.1 \%$. Only the permutation of these variables reduces the model's prediction to nearly $60.2 \%$. Consequently, these variables were the most decisive in predicting the spatio-temporal dynamics of the agroecological zones of Sorghum bicolor distribution. However, rainfall in the driest quarter (bio17) and dry months $(\mathrm{dm})$ had little influence on the discrimination of these zones.

\subsection{Predictive Capacity of the Model and Results of the Jackknife Test Regarding the Different Climate Scenarios}

Figures 2-4 present, respectively, the results of the Jackknife test on the importance of the variables used in terms of information gain for RCP scenarios 2.5, 


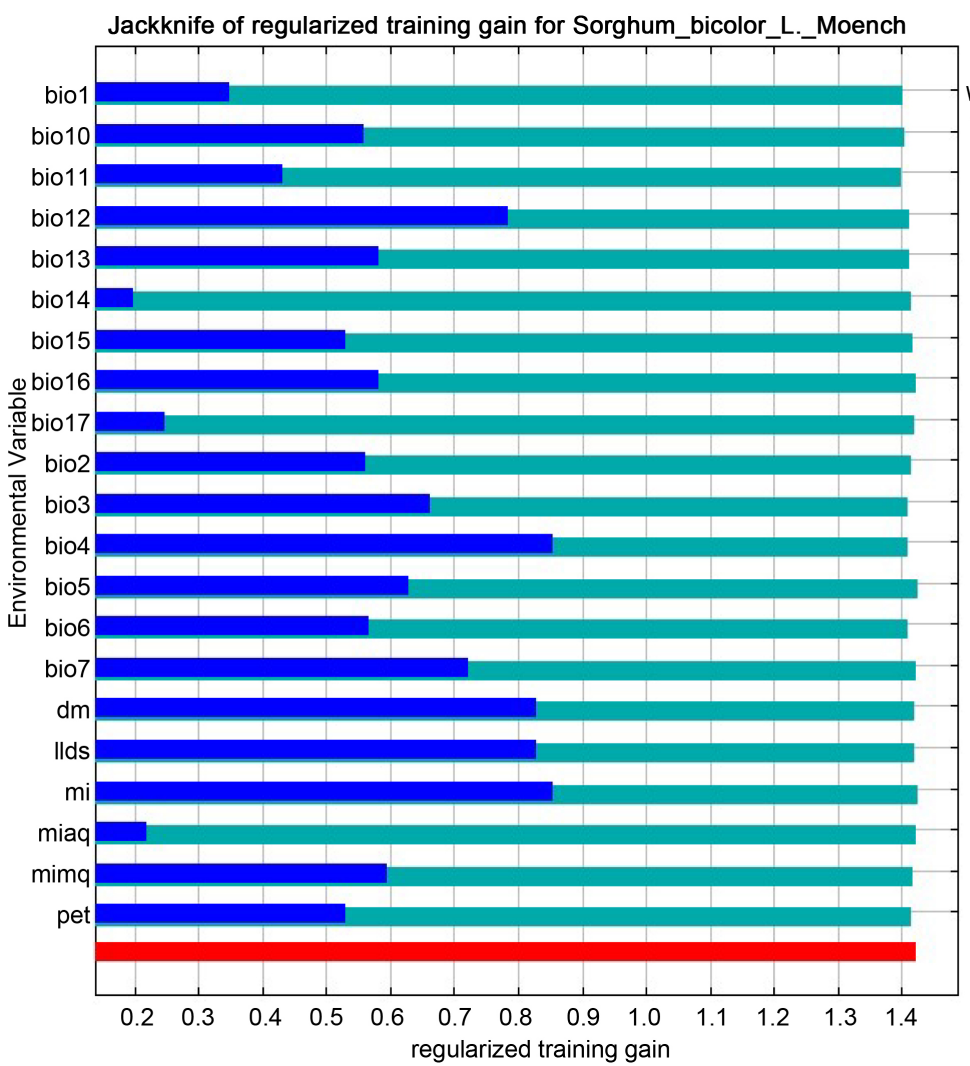

Without variable With only variable With all variables *

Figure 2. Jackknife test results for the RCP 2.5 Scenario.

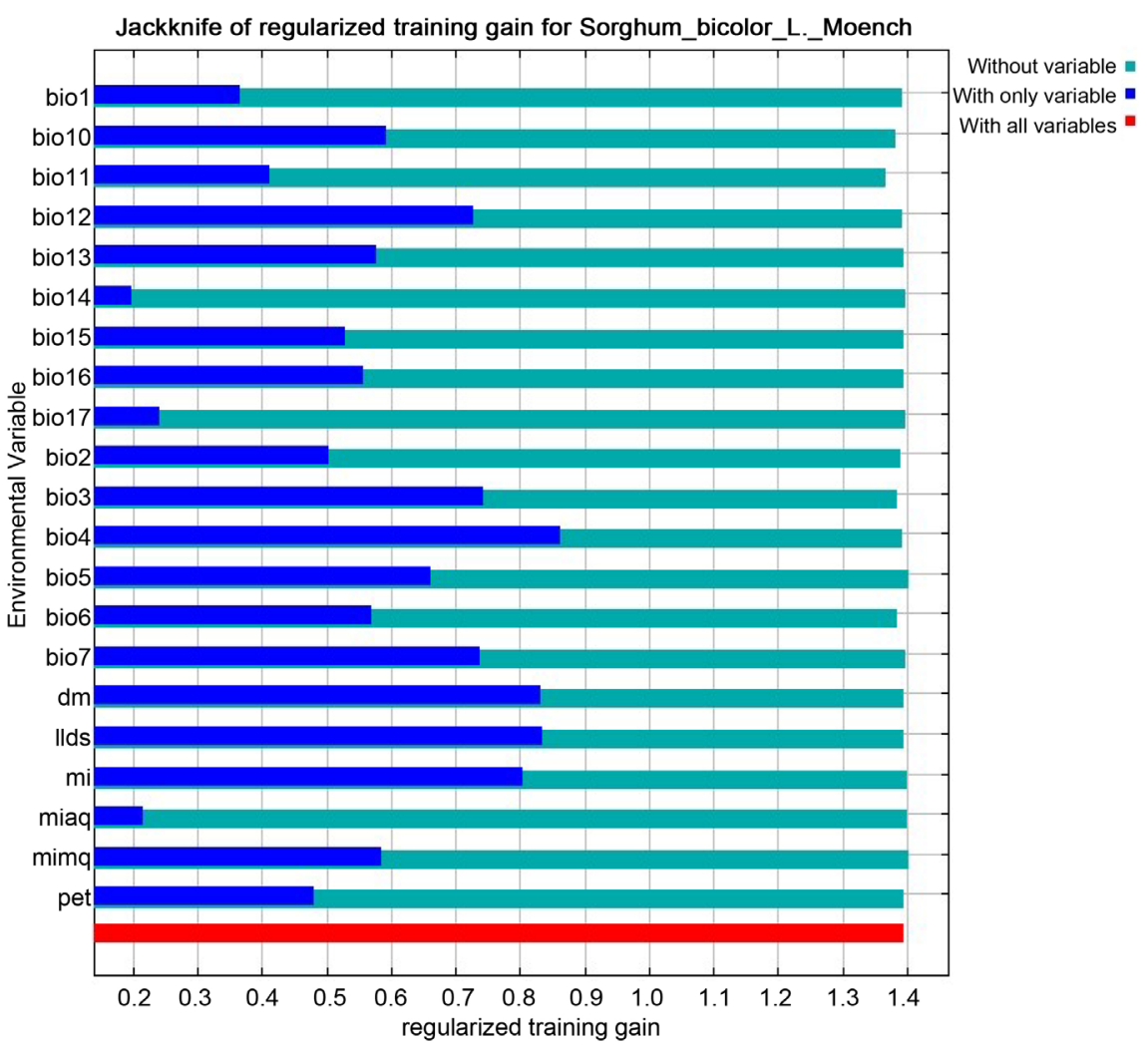

Figure 3. Jackknife test results considering Scenario 4.5. 


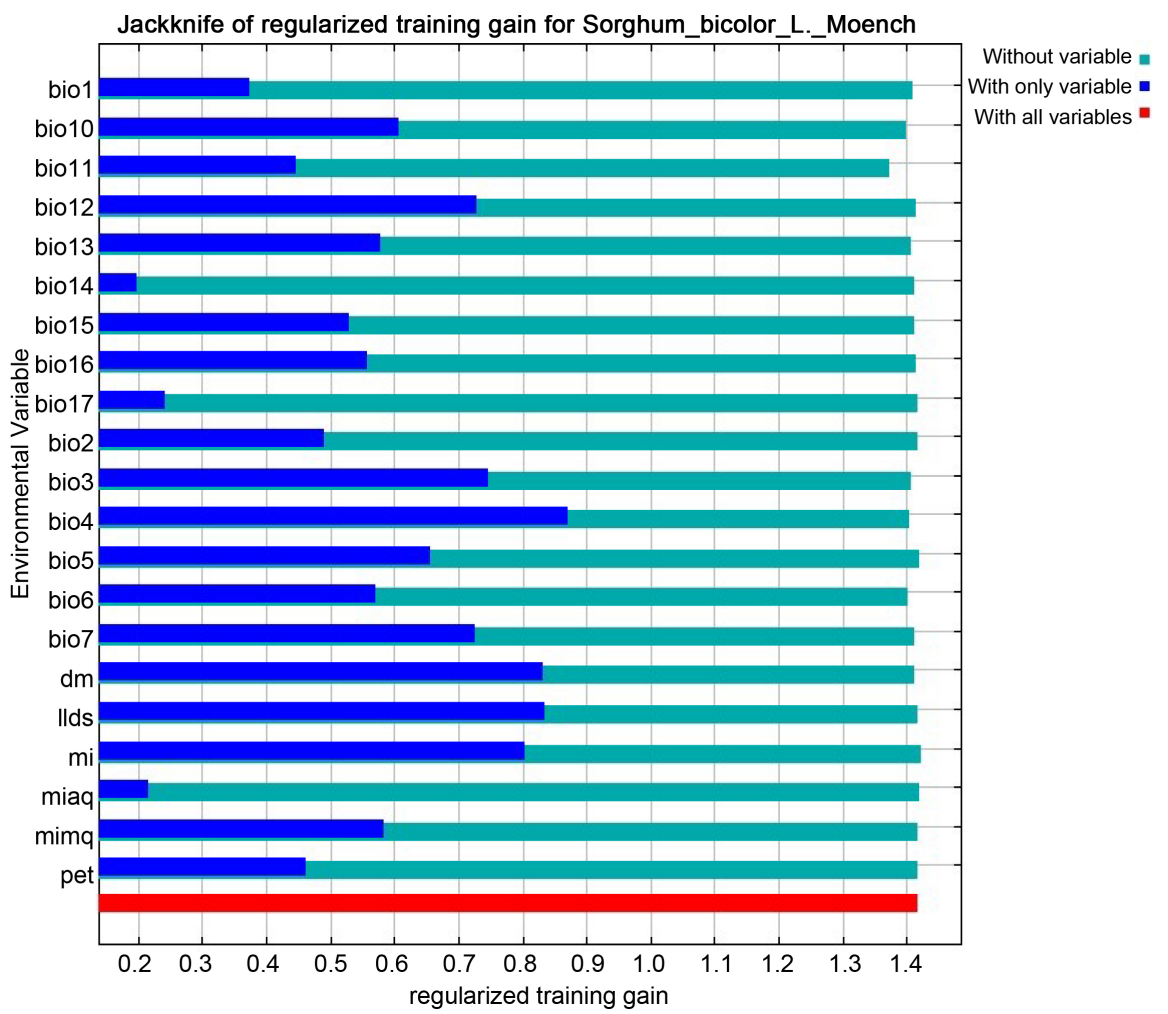

Figure 4. Jackknife test results for the RCP 8.5 Scenario.

4.5 , and 8.5 respectively. The statistics for assessing the predictive power of the model (TSS $=1.42 \pm 1.65$ and AUC $=0.93 \pm 0.023$ ) indicate good performance of the model in predicting the spatial-temporal dynamics of Sorghum bicolor habitat in the study environment considering current conditions. The variables that increase the gain in information explaining the distribution of sorghum (Figure 2) when the variables are used individually are: rainfall (bio4) and moisture index (mi) followed by number of dry months $(\mathrm{dm})$ and values of the length of the longest dry season (IIds).

Considering the optimistic scenario, the mean values of TSS $(1.39 \pm 1.616)$ and AUC $(0.93 \pm 0.024)$ indicate good performance of the model in predicting the spatio-temporal dynamics of sorghum habitat in the two agroecological zones considering the scenario. The results of the Jackknife test on the importance of the variables used in the optimistic scenario (Figure 3) showed that the variable that increases the information gain explaining the distribution of sorghum regarding the rainfall variable (bio4), followed by number of dry months (dm), length of the longest dry season (IIds) and the moisture index (mi).

The values of TSS obtained $(0.42 \pm 1.63)$ and AUC $(0.93 \pm 0.02)$ indicate good performance of the model in predicting the spatiotemporal dynamics of sorghum habitat in the two agro-ecological zones. From the results of Figure 4, it appears that variable that increases the gain of information explaining the distribution of Sorghum bicolor when isolated is rainfall (bio4) followed by number of dry months (dm), duration of the longest dry season (IIds) and humidity in- 
dex (mi). Finally, the model for predicting the spatiotemporal dynamics of sorghum in the two districts is efficient considering the three scenarios.

\subsection{Dynamics of Current and Future Sorghum Production Areas in the Sudanian and Sahelian Zone of Mali}

The observed variations in sorghum growing areas in the Sudanian and Sahelian zones are presented in Table 5 and Table 6 respectively. The dynamics of current and future sorghum growing areas show variations in space and time. The proportion of sorghum cultivation area varies from one scenario to another in the Sudanian zone (Table 5). Under the current climatic conditions, the completely suitable and suitable areas for sorghum cultivation represent the major part of the total area of this zone. The completely suitable zones are located in the East and extend to the West of the Sudanian region while the suitable zones extend over the Southeast, the center and part of the West (Figure 5). The non suitable zones do not dominate in this area. The completely non suitable zones (5\% of the total area) are located in the extreme North-central and South. Considering the optimistic or pessimistic scenarios, it is observed an increase by 2050 in the non suitable and completely non suitable zones for sorghum cultivation in the Sudanian region (Table 5). In the context of an increase in greenhouse gas emissions (RCP 8.5 scenario), a decrease of $24 \%$ will be noted in the areas completely suitable for sorghum cultivation by 2050 . Finally, by 2050, there will be a decrease in the areas suitable for sorghum cultivation in the Sudanian zone. Furthermore, in the Sahelian region, the current climatic conditions show that $69 \%$ of the area is completely suitable and suitable for sorghum cultivation. The areas that are completely suitable for sorghum cultivation are located in the North and part of the centre of the Sahelian region while the suitable ones are located in the extreme central-eastern and central-western parts of the area (Figure 6). An increase in suitable areas will be noted as well as a decrease of the non suitable areas, while considering an increase of the greenhouse gases (CPR 8.5 scenario), an increase in the areas non suitable for sorghum cultivation in the Sahelian region by 2050 will be observed. The suitable areas will be located in the northern and northwestern part of the zone (Figure 6). In this context, there is a risk of displacement of agricultural populations. The south-central part of the region will concentrate more areas that are completely non suitable for sorghum cultivation.

Table 5. Current and future sorghum growing areas in the Sudanian region.

\begin{tabular}{crrcrcrc}
\hline \multirow{2}{*}{ Growing area } & RCP 2.5 & & RCP4.5 & \multicolumn{2}{c}{ RCP8.5 } \\
\cline { 2 - 7 } & Surface $\left(\mathrm{km}^{2}\right)$ & $\%$ & Surface $\left(\mathrm{km}^{2}\right)$ & $\%$ & Surface $\left(\mathrm{km}^{2}\right)$ & $\%$ \\
\hline Completely non suitable & 28,970 & 5 & 89,920 & 15 & 147,163 & 25 \\
Non suitable & 153,925 & 26 & 108,414 & 18 & 150,003 & 24 \\
Suitable & 192,679 & 32 & 96,354 & 16 & 140,479 & 24 \\
Completely suitable & 2195,90 & 37 & 3012,84 & 51 & 1581,37 & 27 \\
\hline
\end{tabular}


Table 6. Current and future sorghumgrowing areasin the Sahelian zone.

\begin{tabular}{ccccccc}
\hline & \multicolumn{2}{c}{ RCP2.5 } & \multicolumn{2}{c}{ RCP4.5 } & \multicolumn{2}{c}{ RCP8.5 } \\
\cline { 2 - 7 } Growing area & $\begin{array}{c}\text { Surface } \\
\left(\mathrm{km}^{2}\right)\end{array}$ & $\%$ & $\begin{array}{c}\text { Surface } \\
\left(\mathrm{km}^{2}\right)\end{array}$ & $\%$ & $\begin{array}{c}\text { Surface } \\
\left(\mathrm{km}^{2}\right)\end{array}$ & $\%$ \\
\hline Completely non suitable & 95,039 & 16 & 62,161 & 10 & 119,071 & 20 \\
suitable & 93,113 & 16 & 157,425 & 26 & 140,344 & 23 \\
Suitable & 75,809 & 13 & 196,363 & 33 & 157,122 & 26 \\
Completelysuitable & 336,155 & 55 & 184,868 & 31 & 183,922 & 31 \\
\hline
\end{tabular}

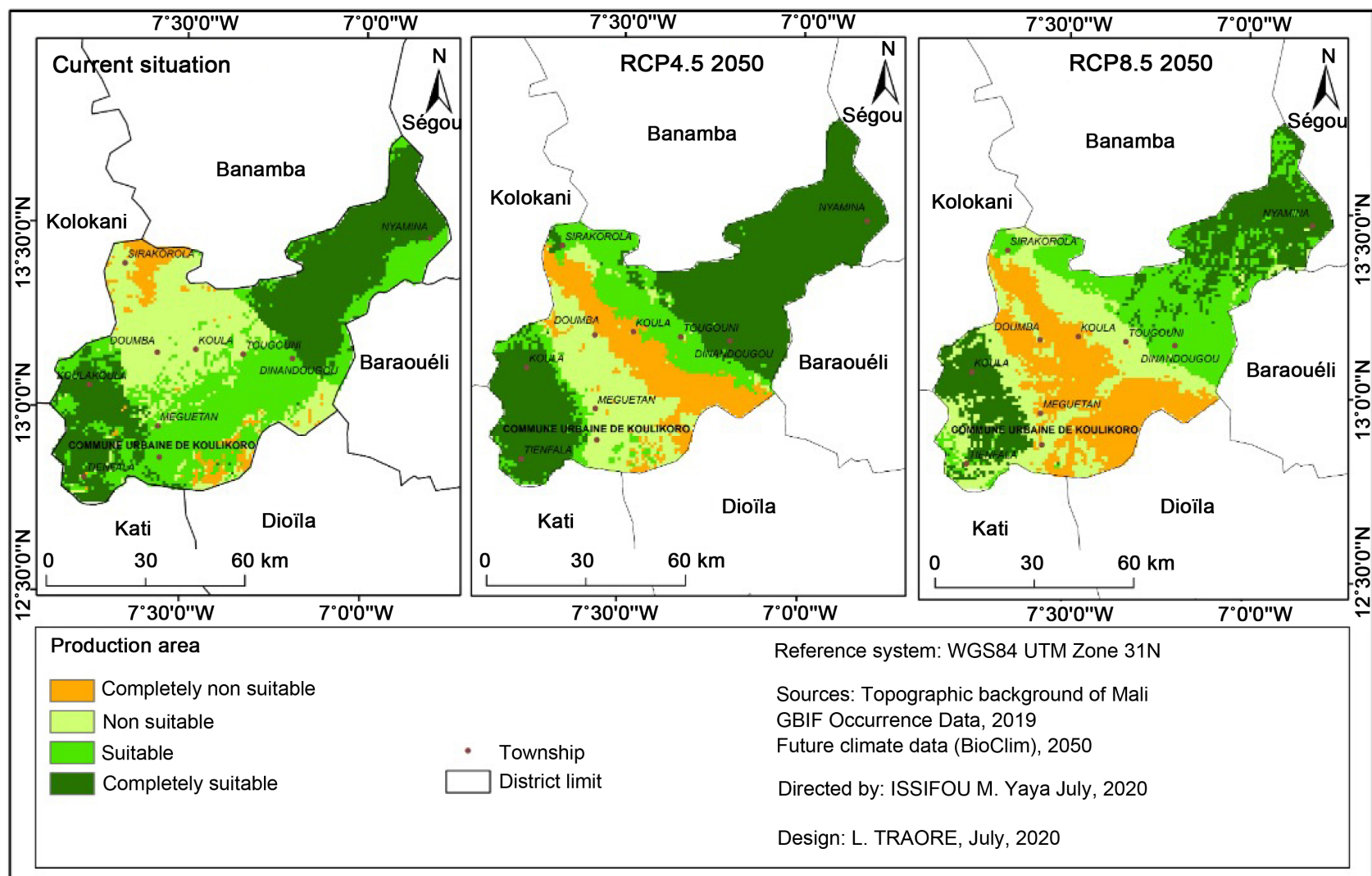

Figure 5. Current and future distribution areas for sorghum cultivation in the Sudanian zone.

\section{Discussion}

\subsection{Model Performance Suitability and Probability of Occurrence Response to the Environmental Variables}

The modeling of sorghum growing areas in the Sudanian and Sahelian zones was carried out based on the Maxent (Maximum Entropy) principle (Phillips et al., 2006). This approach is based on the fundamental concept of the niche of Hutchinson (1957) which represents the intervals of conditions and resources existing in a given space and which is potentially exploitable by a species, without taking into account the possible biotic interactions with other species (Ricklefs, 2010; Soufiyanou et al., 2019). This approach takes into account the coexistence of species implying a certain dissimilarity (even if this is not highlighted) as well 


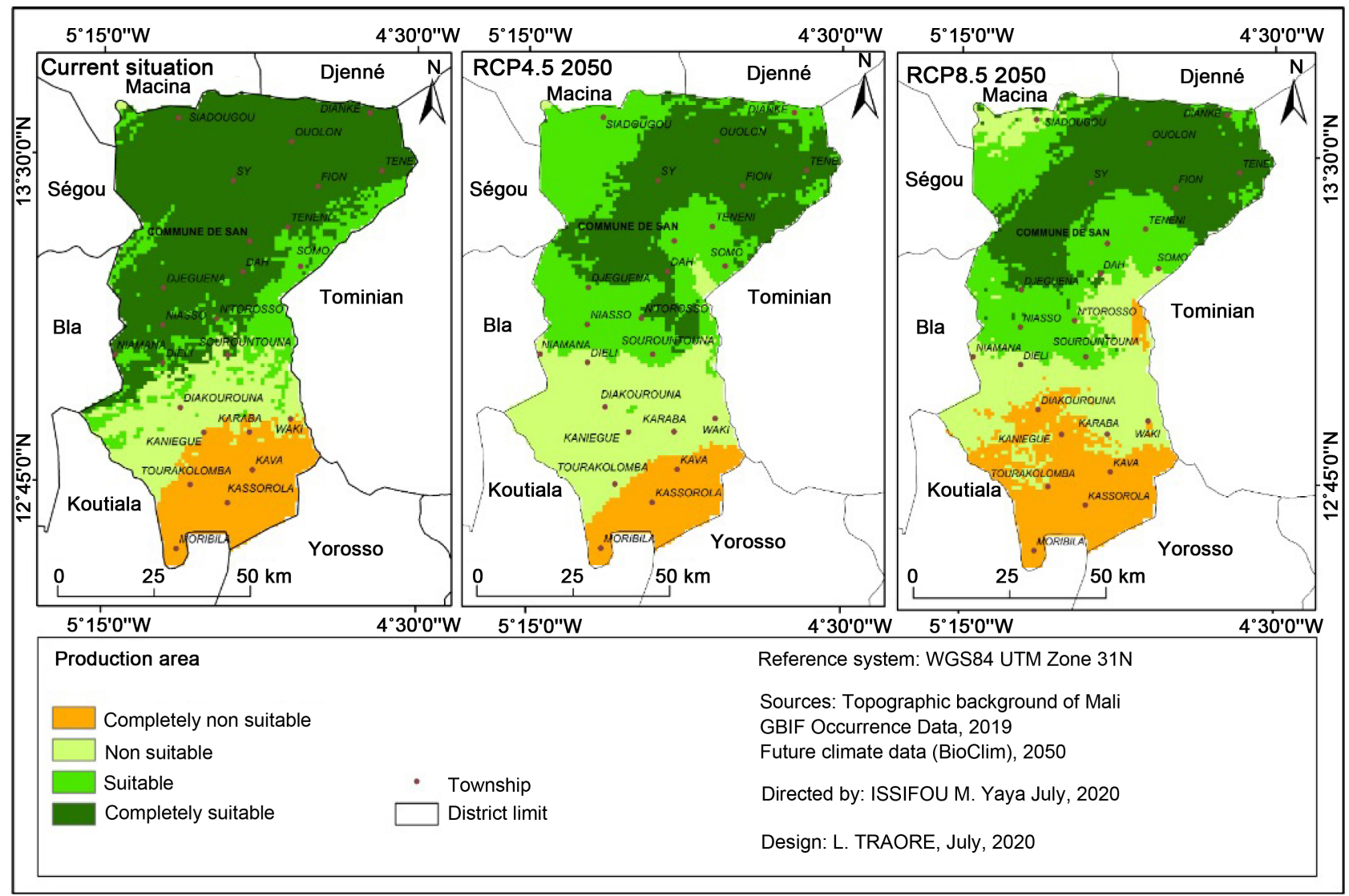

Figure 6. Current and future distribution areasfo sorghum cultivation in the Sahelian zone.

as the empirical principle (the objective is to predict via niche measurements the coexistence or exclusion, or, via observation of coexistence, the minimal dissimilarity of niches (Hutchinson, 1957)). Predictive models are generally used by scientists for the protection of plant species and to estimate their spatial distribution (Dotchamou et al., 2016). These models are used to determine which plants are in danger of extinction (Ortega-Huerta \& Peterson, 2004; Dotchamou et al., 2016), to calculate the probabilities of species invasion (Fandohan et al., 2015) and to assess the impacts of climate change on species distribution (Dotchamou et al., 2016). Ecological niche modelling has often been considered as a powerful tool for mapping the current and future distribution of species and predicting the impact of climate change on their distribution (van Zonneveld et al., 2009; Fandohan et al., 2013). Indeed, these models were subjected to much criticism because of their weaknesses in predicting the impact of climate change on the geographical distribution of species (Fandohan et al., 2013). Among these weaknesses are the uncertainties related to the models used, difficulties in parameterizing ecological interactions, individual species idiosyncratic responses to climate change, species-specific release limitations, the plasticity of physiological limits and adaptive responses of disseminating agents (Elith et al., 2006; Schwartz, 2012). Indeed, fewer uncertainties related to the models used are observed, notably the difficulties in determining the parameters of ecological interactions and 
the propagation limits specific to each species (Schwartz, 2012). The modelling of ecological niches has many applications and is mainly used to propose scenarios for sustainable use of the environment (Beaumont et al., 2007), and to assess the impacts of climate change on biodiversity (Araújo et al., 2005; Araújo \& Luoto, 2007).

\subsection{Impact of Climate Change on the Distribution of Sorghum bicolor in the Study Area}

The order of integration of the variables in the prediction model revealed that rainfall of the wettest quarter, seasonality of rainfall, rainfall of the wettest month, annual rainfall, had positive impact on the prediction of sorghum growing areas. The abundance of rainfall is the main factor that determines the quantity and quality of plant growth (PSSP, 2009), according to Camberlin et al. (2007). But according to Tennant and Hewitson (2002) and Boyard-Micheau (2013), the seasonal accumulation did not represent sufficient information for the agricultural sector insofar as a season with high accumulation can contain long dry spells potentially harmful to the good development of crops. Such situation was all the more harmful if these dry periods occur during the flowering or grain-filling phase of the crops (Sultan et al., 2005). Variables such as the intra-seasonal distribution of rainfall or the start and end dates of the season must be taken into consideration as they influence yields and determine the agricultural calendar. These results corroborate with those obtained by Sene (1995) showing that production of dry matter by the plant is a function of the quantity of water and mineral salts absorbed. This absorption depends on external and internal factors, especially climatic factors of the moment (FTE for example) and the genetic heritage of the plant whose water and mineral salts needs are variable during the development cycle. The analysis of the results of the habitat prediction model revealed that annual temperature variation, mean daily temperature variation, ratio of daily thermal amplitude to annual thermal amplitude introduced in the model had a positive impact in predicting the habitats of Sorghum bicolor. According to Bougma et al. (2018), high temperatures cause considerable reduction in the pollen viability, leading consequently to sterility of spikelet and negative effects on yields.

\subsection{Implications of the Study}

The reduction of nearly $57.1 \%$ (scenario RCP 2.4 ), 57.2\% (scenario RCP 4.5) and $60.2 \%$ (scenario RCP $8.5 \%$ ) in the predictive power of the observed model when the variables studied are permuted justify their determining roles in the prediction of the spatio-temporal dynamics of the sorghum growing areas.

Indeed, these variables act in direct symbiosis on the plants and constitute the major climatic parameters in plant ecology and are determinant for the prediction of the spatio-temporal dynamics of species production areas (Dossou et al., 2016; Hounkpêvi et al., 2016; Fandohan et al., 2015; Soufiyanou et al., 2019). The current climatic conditions (scenario RCP 2.5) indicate that the production areas 
in the East and West of the Sudanian region are and will remain completely suitable for the cultivation of Sorghum bicolor by 2050. However, the production areas in the south-east, the center and part of the West are respectively suitable and non suitable production areas. The less suitable production area will be the north-central, the extreme south-central and the completely non suitable areas will be the extreme north-central and south-central considering the current and future climatic scenarios.

The future climatic condition (scenario RCP 4.5) showed that the production zones in the East and West of the Sudanian region are and will remain completely suitable for Sorghum bicolor cultivation by 2050. The non suitable production zones will be the center-west zones (between suitable and completely suitable zones). The completely non suitable zones will be the center (between suitable and non suitable zones) considering the current and future climatic conditions. The future climatic conditions (scenario RCP 8.5) show that the completely suitable production areas in the East and West of the Sudanian region will decrease in favor of area suitable to the cultivation of Sorghum bicolor by 2050. However, the suitable zone for Sorghum bicolor production will be the centre toward the East. The non suitable production zones will be in the center-West areas. This could be explained by the fact that the distribution and abundance of sorghum evolves according to the climatic gradient of the Sudanian region. Indeed, the climatic gradient of the Sudanian region evolves in an increasing and decreasing way from East to West. These results corroborate Soumaré (2004) showing that the crop varies from $5 \%$ in the East to $40 \%$ in the West.

The current climatic conditions (RCP 2.5) indicated that the production zones from the center to the east of the Sahelian region occupy more than half of the zones fully suitable to the cultivation of Sorghum bicolor by 2050. On the other hand, the zones production in the south-east, the center and part of the west are respectively suitable. The non suitable areas occupy about a quarter of the sorghum production areas and are located in the center-south, in the extreme center-south. The fully non suitable areas also occupy a quarter of the sorghum production areas and are located in the south under current and future climatic conditions.

Future climatic conditions (RCP 4.5) show that the fully suitable production areas in the east of the Sahel region will be reduced by $24 \%$ in favor of areas suit-able to the cultivation of Sorghum bicolor by 2050. On the other hand, the bicolor sorghum production areas in the east will drop by $33 \%$. The non suitable production areas will be increased by $26 \%$ in the center-west. The fully non suitable areas will be reduced by $10 \%$ in the east under current and future climatic conditions. Future climatic conditions (RCP 8.5) show that the fully suitable production areas in the east will be reduced by $31 \%$ of the Sahel region in favor of areas suitable to the cultivation of Sorghum bicolor by 2050. On the other hand, the bicolor sorghum production areas suitable areas will increase by 
$26 \%$ from the center to the east. The non suitable production areas will be $23 \%$ at the center level. Fully non suitable areas will increase by $20 \%$ in the west under current and future climatic conditions. The current potential of sorghum growing areas was sensitive to the predictions of the two scenarios applied for 2050. This shows that climate change may impact the sorghum growing areas in both agro-ecological zones, especially the distribution and abundance of ecotypes (Guisan \& Zimmermann, 2000; Thomas et al., 2015; Renner et al., 2015). Considering the extent of the production areas obtained by the gross probability values greater than or equal to 0.5 generated by the model, we can deduce that whatever the scenario used, climate change will constitute a serious threat to the survival of sorghum crop by 2050 in both the Sudanian and Sahelian zones of Mali.

\section{Conclusion}

Modelling of sorghum growing areas in the Sudanian and Sahelian zones using the Maxent (Maximum Entropy) model showed that the model is effective in predicting the spatiotemporal dynamics of sorghum growing areas in the two agro-ecological zones. The future distribution of sorghum in the two agro-ecological zones will be determined by the seasonality of rainfall, annual rainfall, the number of dry months, and the wet-quarter moisture index, rainfall in the wettest month, the annual variation in temperature and the average daily variation in temperature. In a perspective of greenhouse gas mitigation and emission, climate variations will reduce the areas suitable for sorghum cultivation in the Sudanian and Sahelian zones of Mali. It is, therefore, suggested to carry out investigations on potential sorghum yield prediction in both study areas in order to identify suitable production areas of the crop in the near future (2050) and long term (2100) as adaptation strategies and resilience of farmers to climate change.

\section{Acknowledgements}

The research team would like to express their sincere thanks to the Project for Capacity Building of Higher Education Institutions in Integrated Water Resources Management (IES4GIRE NICHE_MLI_251) in Mali for funding the present research work. The team also thanks the two anonymous referees for their useful comments and inputs.

\section{Conflicts of Interest}

The authors declare no conflicts of interest regarding the publication of this paper.

\section{References}

Allouche, O., Tsoar, A., \& Kadmon, R. (2006). Assessing the Accuracy of Species Distribution Models: Prevalence, Kappa and the True Skill Statistic (TSS). Journal of Applied Ecology, 43, 1223-1232. https://doi.org/10.1111/j.1365-2664.2006.01214.x 
Araújo, M. B., \& Luoto, M. (2007). The Importance of Biotic Interactions for Modelling Species Distributions under Climate Change. Global Ecological Biogeography, 16, 743-753. https://doi.org/10.1111/j.1466-8238.2007.00359.x

Araújo, M. B., Pearson, R. G., Thuiller, W., \& Erhard, M. (2005). Validation of SpeciesClimate Impact Models under Climate Change. Global Change Biology, 11, 1504-1513. https://doi.org/10.1111/j.1365-2486.2005.01000.x

Bakary, K. (2010). Etude de l'efficacité agronomique de microdosage dans un système de rotation biennale de sorgho, niébé dans les conditions de I'IPR/IFRA de katibougou, Mali (78 p.). Thèse de mémoire du diplôme d'Ingénieur de l'IPR/IFRA de Katibougou. Mali.

Beaumont, L. J., Pitman, A. J., Poulsen, M., \& Hughes, L. (2007). Where Will Species Go? Incorporating New Advances in Climate Modelling into Projections of Species Distributions. Global Change Biology, 13, 1368-1385.

https://doi.org/10.1111/j.1365-2486.2007.01357.x

Bougma, L. A., Ouerdraogo, M. H., Sawadogo, N., Sawadogo, M., Balma, D., \& Vernooy, R. (2018). Perceptions paysannes de l'impact du changement climatique sur le mil dans la zone sahélienne et soudano-sahélienne du Burkina Faso. Afrique Science, 14, 264275.

Boyard-Micheau, J. (2013). Prévisibilité potentielle des variables climatiques à impact agricole en Afrique de l'Est et application au sorgho dans la région du mont Kenya (338 p.). Doctoral Dissertation, Dijon.

Camberlin, P., Martiny, N., Philippon, N., \& Richard, Y. (2007). Determinants of the Interannual Relationships between Remote Sensed Photosynthetic Activity and Rainfall in Tropical Africa. Remote Sensing of Environment, 106, 199-216.

https://doi.org/10.1016/j.rse.2006.08.009

Coumbiti, D. (2019). Effet de la fertilisation sur le comportement du riz irrigué en système de riziculture intensif (SRI) dans les conditions agroclimatiques de San, Mali (40 p.). Thèse de mémoire du diplôme d'Ingénieur de l'IPR/IFRA de Katibougou, Mali.

Dossou, E. M., Lougbégnon, T. O., Houessou, L. G., \& Codjia, J. T. C. (2016). Analyse de l'impact du changement climatique sur l'aire de distribution actuelle et future de Lannea microcarpa Engl, \& K, Krause au Bénin, Afrique de l'Ouest. Afrique Science, 12, 27-38.

Dotchamou, F. T., Atindogbe, G., Sode, A. I., \& Fonton, H. N. (2016). Density and Spatial Pattern of Parkia biglobosa under Climate Change: The Case of Benin. Journal of Agriculture and Environment for International Development, 110, 173-194,

Elith, J., Graham, R. P., Anderson, M., Dudik, S., Ferrier, A., Guisan, R. J., Hijmans, F., Huettmann, J. R., Leathwick, A., Lehmann, J., Li, L. G., Lohmann, B. A., Loiselle, G., Manion, C., Moritz, M., Nakamura, Y., Nakazawa, J. M., Overton, A. T., Peterson, S. J., Phillips, K., Richardson, R., Scachetti-Pereira, R. E., Schapire, J., Soberon, S., Williams, M. S., Wisz, N., \& Zimmermann, E. (2006). Novel Methods Improve Prediction of Species' Distributions from Occurrence Data. Ecography, 29, 129-151. https://doi.org/10.1111/j.2006.0906-7590.04596.x

Elith, J., Kearney, M., \& Phillips, S. (2010). The Art of Modelling Range-Shifting Species. Methods in Ecology and Evolution, 1, 330-342. https://doi.org/10.1111/j.2041-210X.2010.00036.x

Fandohan, A. B., Oduor, A. M. O., Sode, A. I., Wu, L., Cuni-Sanchez, A., Assede, E., \& Gouwakinnou, G. N. (2015). Modeling Vulnerability of Protected Areas to Invasion by Chromolaena odorata under Current and Future Climates. Ecosystem Health and Sustainability, 1, 20. https://doi.org/10.1890/EHS15-0003.1 
Fandohan, B., Gouwakinnou, G. N., Fonton, N. H., Sinsin, B., \& Liu, J. (2013). Impact des changements climatiques sur la répartition géographique des aires favorables à la culture et à la conservation des fruitiers sous-utilisés: Cas du tamarinier au Bénin. Biotechnologie, Agronomie, Société et Environnement, 17, 450-462

Franklin, J. (2009). Mapping Species Distribution: Spatial Inference and Prediction (Ecology, Biodiversity and Conservation) Saint Diego State (318 p.). Cambridge: Cambridge University Press.

Giam, X., Bradshaw, C. J. A., Hugh, T. W. T., \& Navjot, S. S. (2010). Future Habitat Loss and the Conservation of Plant Biodiversity. Biological Conservation, 143, 1594-1602. https://doi.org/10.1016/j.biocon.2010.04.019

Guisan, A., \& Zimmermann, N. E. (2000). Predictive Habitat Distribution Models in Ecology. Ecological Modelling, 135, 147-186. https://doi.org/10.1016/S0304-3800(00)00354-9

Hounkpêvi, A., Tosso, F., Gèmavo, D. S. J. C., Kouassi, E. K., Koné, D., \& Glèlè-Kakaï, R. (2016). Climate and Potential Habitat Suitability for Cultivation and in Situ Conservation of the Black Plum (Vitex doniana Sweet) in Benin, West Africa. International Journal of Agronomy and Agricultural Research, 8, 67-80.

Hutchinson, G. E. (1957). Concluding Remarks. Cold Spring Harbor Symposia on Quantitative Biology, 22, 415-457. https://doi.org/10.1101/SQB.1957.022.01.039

IPCC (2013). Climate Change 2013: The Physical Science Basis. IPCC Working Group I Contribution to the IPCC Fifth Assessment Report. New York: Cambridge University Press.

Lobell, D. B., \& Field, C. B. (2007). Global Scale Climate-Crop Yield Relationships and the Impacts of Recent Warming. Environmental Research Letters, 2, Article ID: 014002. https://doi.org/10.1088/1748-9326/2/1/014002

Newman, T. P. (2016). Tracking the Release of IPCC AR5 on Twitter: Users, Comments, and Sources Following the Release of the Working Group I Summary for Policy Makers. Public Understanding of Science, 26, 815-825.

https://doi.org/10.1177/0963662516628477

Ortega-Huerta, M. A., \& Peterson, A. T. (2004). Modelling Spatial Patterns of Biodiversity for Conservation Prioritization in North-Eastern Mexico. Diversity and Distributions, 10, 39-54. https://doi.org/10.1111/j.1472-4642.2004.00051.x

Ouattara, I., Diarra, Y., \& Mariko, S. (2019). Etude des Impacts des Changements Climatiques sur les Activités Agricoles dans la Commune Rurale de Mafouné, Cercle de Tominian, Région de Ségou au Mali. European Scientific Journal, 15, 121-144. https://doi.org/10.19044/esj.2019.v15n11p121

Padalia, H., Srivastava, V., \& Kushwaha, S. P. S. (2014). Modeling Potential Invasion Range of Alien Invasive Species, Hyptis suaveolens (L.) Poit. in India: Comparison of MaxEnt and GARP. Ecological Informatics, 22, 36-43. https://doi.org/10.1016/j.ecoinf.2014.04.002

Phillips, S. J., Anderson, R. P., \& Schapire, R. E. (2006). Maximum Entropy Modeling of Species Geographic Distributions. Ecological Modelling, 190, 231-259. https://doi.org/10.1016/j.ecolmodel.2005.03.026

Platts, P. J., Marchant, R. A. (2015). AFRICLIM: High-Resolution Climate Projections for Ecological Applications in Africa. African Journal of Ecology, 53, 103-108. https://doi.org/10.1111/aje.12180

PSSP (Projet de Sécurisation des Systèmes Pastoraux) (2009). La mobilité pastorale dans la région de Zinder, IRAM-Karkara/AFD (113 p.).

Renner, I. W., Elith, J., Baddeley, A., Fithian, W., Hastie, T., Phillips, S. J., Popovic, G., \& 
Warton, D. I. (2015). Point Process Models for Presence-Only Analysis. Methods in Ecology and Evolution, 6, 366-379. https://doi.org/10.1111/2041-210X.12352

Ricklefs, R. E. (2010). A Economia da Natureza (570 p.). Rio de Janeiro: Guanabara Koogan.

Schwartz, M. W. (2012). Using Niche Models with Climate Projections to Inform Conservation Management Decisions. Biological Conservation, 155, 149-156. https://doi.org/10.1016/j.biocon.2012.06.011

Sene, L. (1995). Réponse de la variété de sorgho CE 145-66 à l'alimentation en eau: Effets du stress hydrique sur le rendement et la qualité des semences (59 p.). Mémoire d'ingénieur en travaux agricoles, ENCR, CNRA de Bambey.

Sinclair, T. R., Marrou, H., Soltani, A., Vadez, V., \& Chandolu, K. C. (2014). Soybean Production Potential in Africa. Global Food Security, 3, 31-40.

https://doi.org/10.1016/j.gfs.2013.12.001

Soufiyanou, K., Ismaila, T. I., \& Ousséni, A. (2019). Impact de la Variabilité Climatique sur la Niche Ecologique de Diospyros mespiliformis Hochst. ex A. De. dans la Région Soudanienne au Bénin (Afrique de l'Ouest). European Scientific Journal, 15, 2-19. https://doi.org/10.19044/esj.2019.v15n36p1

Soumaré, M. (2004). Contribution à la prévision de l'aire de diffusion de variétés de sorgho au Mali: Couplage entre modèle de croissance des cultures et système d'information géographique (92 p.). Doctoral Dissertation, Université de Paris-Nanterre.

Sultan, B., \& Gaetani, M. (2016). Agriculture in West Africa in the Twenty-First Century: Climate Change and Impacts Scenarios, and Potential for Adaptation. Frontiers in Plant Science, 7, 1262. https://doi.org/10.3389/fpls.2016.01262

Sultan, B., Baron, C., Dingkuhn, M., Sarr, B., \& Janicot, S. (2005). La variabilité climatique en Afrique de l'Ouest aux échelles saisonnière et intra-saisonnière, II: Applications à la sensibilité des rendements agricoles au Sahel. Science et changements planétaires/Sécheresse, 16, 23-33.

Talacuece, M. A. D., Justino, F. B., Rodrigues, R. D. Á., Flores, M. E. P., Nascimento, J. G., \& Santos, E. A. (2016). Modeling of Soybean under Present and Future Climates in Mozambique. Climate, 4, 1-14. https://doi.org/10.3390/cli4020031

Tennant, W. J., \& Hewitson, B. C. (2002). Intra-Seasonal Rainfall Characteristics and Their Importance to the Seasonal Prediction Problem. International Journal of Climatology: A Journal of the Royal Meteorological Society, 22, 1033-1048. https://doi.org/10.1002/joc.778

Thomas, B., Lutz, S., \& Rideau, C. (2015). Modélisation de la répartition des campagnols aquatiques du genre Arvicola en Normandie, GroupeMammalogique Normand, Agence de l'Eau Seine-Normandie (62 p.).

Touré, A. O., \& Diallo, A. G. (2004). Caractéristique et techniques culturales des variétés et hybrides de sorgho au Mali (70 p.). Institut d'Economie rural (IER)/Centre Régional de Recherche Agronomique de Sotuba (CRRA).

Touré, H. A. (2016). Effect of Climate Change and Variability on Pearl Millet (Pennisetum glaucum (L,) $R, B r$,) Production in the Sudanian and Sahelian Agro-Ecological Zones in Mali (183 p.). Doctoral Dissertation.

Traoré, B., Corbeels, M., Van Wijk, M. T., Rufino, M. C., \& Giller, K. E. (2013). Effects of Climate Variability and Climate Change on Crop Production in Southern Mali. European Journal of Agronomy, 49, 115-125. https://doi.org/10.1016/j.eja.2013.04.004

Van Zonneveld, M., Koskela, J., Vinceti, B., \& Jarvis, A. (2009). Impact of Climate Change on the Distribution of Tropical Pines in Southeast Asia. Unasylva, 231/232, 24-29.

Wheeler, T., \& Von Braun, J. (2013). Climate Change Impacts on Global Food Security, Science, 341, 508-513. https://doi.org/10.1126/science.1239402 